\title{
Antioxidant capacity, total phenolic and ascorbate content as a function of the genetic diversity of leek (Allium ampeloprasum var. porrum)
}

\author{
Nathalie Bernaert ${ }^{\mathrm{a}, \mathrm{b}}$, Domien De Paepe ${ }^{\mathrm{b}, \mathrm{f}}$, Charlotte Bouten ${ }^{\mathrm{e}}$, Hervé De Clercq ${ }^{\mathrm{b}}$, Derek Stewart ${ }^{\mathrm{c}}$, \\ Erik Van Bockstaele ${ }^{\mathrm{a}, \mathrm{b}}$, Marc De Loose ${ }^{\mathrm{b}, \mathrm{d}}$, Bart Van Droogenbroeck ${ }^{\mathrm{b}, *}$ \\ ${ }^{a}$ Ghent University, Faculty of Bioscience Engineering, Department of Plant Production, Coupure Links 653, 9000 Ghent, Belgium \\ ${ }^{\mathrm{b}}$ Institute for Agricultural and Fisheries Research (ILVO), Technology and Food Science Unit, Product Quality and Innovation Research Group, Burg. Van Gansberghelaan 115, \\ 9820 Merelbeke, Belgium \\ ${ }^{\mathrm{c} J a m e s}$ Hutton Institute (JHI), Invergowrie, Dundee, DD2 5DA, Scotland, UK \\ ${ }^{\mathrm{d}}$ Ghent University, Faculty of Science, Department of Plant Biotechnology and Genetics, K.L. Ledeganckstraat 35, 9000 Ghent, Belgium \\ e University College Ghent, Department, Biosciences and Landscape Architecture, Voskenslaan 270, 9000 Ghent, Belgium \\ ${ }^{\mathrm{f}}$ Flemish Institute for Technological Research (VITO), Business Unit Environmental Analysis and Technology (MANT), Boeretang 200, 2400 Mol, Belgium
}

\section{A R T I C L E I N F O}

\section{Article history:}

Received 10 August 2011

Received in revised form 22 February 2012

Accepted 26 February 2012

Available online 8 March 2012

\section{Keywords:}

Allium ampeloprasum var. porrum

Antioxidant capacity

ORAC

FRAP

DPPH

Total phenolic content

L-Ascorbic acid content

\begin{abstract}
A B S T R A C T
Extracts of the white shaft and green leaves of 30 leek cultivars were investigated for their antioxidant properties, total phenolic (TP) and L-ascorbic acid (AA) content. The measured antioxidant properties included free radical scavenging activities against peroxyl (ORAC) and 2,2-diphenyl-1-picrylhydrazyl radicals (DPPH) and their $\mathrm{Fe}^{3+}$ reducing capacity (FRAP). The results from this study suggest that the green leek leaves generally have significantly stronger antioxidant properties than the white shaft. Correlation analysis between the TP and the AA content and the antioxidant activity showed that phenolics and ascorbic acid contribute significantly to the antioxidant activity of leek. The three antioxidant activity assays were all correlated for the extracts of the white shaft of the 30 leek cultivars. Principal component analysis (PCA) elucidated the influence of part and type of cultivar on the antioxidant capacity, TP, and Lascorbic acid content, whilst the breeding strategy and seed company had no influence.
\end{abstract}

(c) 2012 Elsevier Ltd. All rights reserved.

\section{Introduction}

An increasing number of studies indicate that increased consumption of fruits and vegetables can reduce the risk of chronic degenerative diseases such as cardiovascular disease, cancers, and others (Boffetta et al., 2010; Gandini, Merzenich, Robertson, \& Boyle, 2000; van Duijnhoven et al., 2009). The associated beneficial effects have been attributed to various components but in general to those that, in vitro at least, act as antioxidants including phenolics, ascorbic acid, carotenoids and tocopherols (Ames, Shigenaga, \& Hagen, 1993; Halliwell, 1996; Huxley \& Neil, 2003; Knekt et al., 2002). In model systems, free radicals, which are capable of causing damage to DNA, proteins and lipids, have been associated with carcinogenesis, coronary heart disease, and many other health problems (Dai \& Rabinovitch, 2009; Lu, Lin, Yao, \& Chen, 2010; Shen, 2010). This has driven researchers to search for a link between reduced risk of degenerative diseases and dietary-related antioxidant

\footnotetext{
* Corresponding author. Tel.: +32 927228 39; fax: +32 92722801.

E-mail address: Bart.Vandroogenbroeck@ilvo.vlaanderen.be (B. Van Droogenbroeck).
}

intake via prevention of cellular oxidative damage (Evans \& Halliwell, 2001; Thaipong, Boonprakob, Crosby, Cisneros-Zevallos, \& Byrne, 2006).

Leek (Allium ampeloprasum var. porrum) is one of the most important field vegetable crops in Flanders, accounting for $16 \%$ of the total agricultural production value (Platteau, Van Gijseghem, \& Van Bogaert, 2010). Compared to other Allium crops, leek is very tolerant to cold weather, although the optimum temperature for vegetative growth is around $20^{\circ} \mathrm{C}$. Local landraces, adapted to different climates and market demands, have been developed in many European countries from Bulgaria to Ireland and in other parts of the world (e.g., Middle East). The early leek cultivars were actually landraces and were highly variable in agronomic and morphological treats. During the second half of the 20th century, numerous new cultivars were developed. Winter-hardiness, long shafts in winter varieties, erectness of the leaves and dark leaf colour were the desirable traits. Nowadays F1 hybrids are gaining popularity among growers, due to their higher yields and improved uniformity compared with open-pollinated cultivars (De Clercq \& Van Bockstaele, 2002). These selection and breeding efforts resulted in different types of leek cultivars, each specifically adapted for growth in a 
specific part of the leek production season. In Belgium, the summer leek types are harvested from June until October, the autumn types from September until January and the winter types from December until May. As a result, leek is supplied to the market year-round by combining different production methods and cultivars optimised for growth either in protected conditions or in the field for summer, autumn and winter harvest. Leek is a monocotyledonous plant of the Alliaceae family and is grown in Belgium for its thickened cylindrical white shaft made up of long leaf bases. Leek, normally a biennial crop, is grown as a short-lived annual in commercial cropping (Burt, 2011). Leek is predominantly a Eurocentric crop (De Clercq, Peusens, Roldan-Ruiz, \& Van Bockstaele, 2003) with significant cultivation in Turkey (10000 ha), France (6200 ha), Belgium (4700 ha) and Poland (4800 ha). In 2008, 33,800 ha were dedicated to leek cultivation in Europe. This coverage equates to $\sim 0.72 \mathrm{M}$ tonnes (Eurostat, 2010).

Research on the nutritive and health benefits of leek is scarce but the medicinal value of leek and the other Alliaceae (e.g. garlic and onion), together with their characteristic flavours have been recognised for thousands of years (Augusti, 1990; Carson, 1987; Lawson, Biological Activity. Lawson, \& Bauer, 1998). The Allium genus, which includes about 700 species, has been recognised as a rich source of secondary metabolites (Havey, Galmarini, Gokce, \& Henson, 2004). Its organosulphur compounds, responsible for the organoleptic parameters, are implicated as contributing in part to its health-promoting properties (Lanzotti, 2006; Mostafa, Mima, Ohnishi, \& Mori, 2000; Singh et al., 1998; Xiao, Pinto, Gundersen, \& Weinstein, 2005; Yin, Hwang, \& Chan, 2002). In addition, a wealth of other classes of compounds, such as polyphenolics including flavonol glycosides are also suggested to contribute to the healthpromoting properties of these species (Lanzotti, 2006). Several kaempferol glycosides have been reported in leek (Fattorusso, Lanzotti, Taglialatela-Scafati, \& Cicala, 2001). Leek also contains significant levels of lutein, $\beta$-carotene, vitamin $\mathrm{C}$ and vitamin $\mathrm{E}$ (Hart \& Scott, 1995; Proteggente et al., 2002).

The measurement of the antioxidant activity of food products and ingredients is a matter of growing interest. In addition to the presumed association with health benefits, antioxidants may inhibit, retard or ameliorate oxidative spoilage (Huang, Ou, \& Prior, 2005; Serrano, Goni, \& Saura-Calixto, 2007; Tsoukalas, Katsanidis, Marantidou, \& Bloukas, 2011; Zulueta, Esteve, \& Frigola, 2009). Determination of the total antioxidant capacity cannot be performed accurately by any single method due to the diversity of phytochemicals present and the associated chemical moiety diversity (Chu, Chang, \& Hsu, 2000). Consequently, at least two different methods should be used to evaluate antioxidant potential/capacity.

Several studies have reported correlations among the antioxidant activities measured by different methods, as well as the correlations between those methods and antioxidant concentrations in various food commodities (Teow et al., 2007; Zhou \& Yu, 2006). However, little information is available on antioxidant activity of leek, particularly among the range of European commercial available and less commonly leek cultivars. These data could be of interest for all the leek producing countries.

The aim of this study was to investigate the antioxidant potential of 30 leek cultivars from different types and (breeding) origins and to determine whether this was related to a gross (phenolic) and specific (ascorbic acid) chemical composition. To this end, three distinct antioxidant capacity assays were used: the oxygen radical absorbance capacity (ORAC) assay, the 2,2-diphenyl-1-picrylhydrazyl (DPPH) radical scavenging activity assay and the ferric reducing antioxidant power assay (FRAP). The ORAC, DPPH and FRAP results, total amounts of phenolics and the L-ascorbic acid content of the white shaft and green leaves of the leek cultivars were used as descriptors for principal component analysis (PCA) in order to differentiate the analysed leek cultivars.

\section{Materials and methods}

\subsection{Plant material}

Thirty leek (Allium ampeloprasum var. porrum) cultivars (Table 1) were studied from a selection based on three criteria: (1) morphological type (pale green summer, dark green winter, intermediate autumn); (2) breeding strategy and multiplication scheme (F1 hybrids, open pollinated cultivars, farmer selections and old landraces); (3) seed company.

The most recently developed cultivars, i.e., the F1 hybrids included in this study, are a good representation of what leek material is commercially grown in the European leek producing areas.

Leek seeds were obtained from the collection of the Institute for Agricultural and Fisheries Research (ILVO). The 30 leek cultivars were sown in triplicate $(3 \times 75$ seeds $)$ in April 2009 in an unheated greenhouse at ILVO. In June 2009, $15(\times 3)$ plants of each cultivar were planted, each repetition in a separate row. During for the cultivar optimal harvest period (Table 1 ) $3 \times 10$ plants (of the $15 \times 3$ ) of each cultivar were manually harvested. Immediately after harvest, the leeks were washed, the roots and decayed leaves were removed, and the remainder was divided into white shaft and green leaf sections. The sections were then chopped into $\sim 1 \mathrm{~cm}^{2}$ pieces. The 10 plants of each replication were pooled. The batches were stored at $-80^{\circ} \mathrm{C}$ (New Brunswick, Rotselaar, Belgium) prior to freeze-drying ( 5 days, $C D$-Energie, Eke, Belgium). The freeze-dried samples were milled to pass through a $1-\mathrm{mm}$ sieve (Fritsch, Rotterdam, The Netherlands) and stored in Falcon tubes at $4{ }^{\circ} \mathrm{C}$ until the time of analysis.

\subsection{Chemicals}

All chemicals were of analytical grade and were purchased from the following: Sigma-Aldrich (UK and Belgium), VWR International (UK and Belgium), Fisher Scientific (UK), Fluka Analytical (Switzerland and UK), Merck (UK and Belgium) and Roche Diagnostics (UK).

\subsection{Spectrophotometric and spectrofluorometric measurements}

ORAC, DPPH and total phenolic analyses were carried out with a FLUOstar OPTIMA plate reader (BMG LABTECH, Offenburg, Germany) equipped with a temperature-controlled incubation chamber. Filters with a wavelength of 485,520 and $740 \mathrm{~nm}$ were purchased from Isogen Life Science (Sint-Pieters-Leeuw, Belgium). The control and evaluation software V2.20 from BMG LABTECH was used for further calculation. The 96 well plates used for the ORAC and DPPH assay and the total phenolic determination were obtained from VWR (UK and Belgium). FRAP analyses were carried out with an Ultraspec 2100 pro (Amersham Biosciences, Buckinghamshire, UK).

\subsection{Sample preparation}

Extraction of the total phenolics in leek was as described by Vinson, Hao, Su, and Zubik (1998) with some slight modifications. Briefly, a precisely weighed (500 mg) amount of freeze-dried leek powder (FDLP) was diluted with $10 \mathrm{ml} 1.2 \mathrm{M} \mathrm{HCl}$ in $50 \%$ aqueous methanol. This mixture was shaken for $2 \mathrm{~h}$ at $80^{\circ} \mathrm{C}$ and centrifuged (4500 rpm, $10 \mathrm{~min}$ ). The supernatant was used for the total phenolic analysis.

Extracts for ascorbic acid (AA) content determination were prepared by adding $1 \mathrm{ml}$ of 5\% metaphosphoric acid (MPA) buffer containing $5 \mathrm{mM}$ tris(2-carboxyethyl)phosphine (TCEP) to an accurately weighed amount $(60 \mathrm{mg})$ of FDLP. In that case, the dehydroascorbic acid (DHA) form of vitamin $\mathrm{C}$ was reduced to ascorbic acid 
Table 1

Overview of the analysed leek cultivars.

\begin{tabular}{|c|c|c|c|c|c|}
\hline Commercial name & Type & Category & Origin & Harvest month & Average weight $\left(\mathrm{kg} \mathrm{plant}^{-1}\right)$ \\
\hline Varna & Summer & Open pollinated & Royal Sluis & October & 0.436 \\
\hline Albana & Summer & Open pollinated & Nunhems & October & 0.489 \\
\hline Nelli & Summer & Old land race & Svalöf Weibull & October & 0.472 \\
\hline Elefant & Summer & Old land race & IPK & October & 0.358 \\
\hline Miracle F1 & Summer & Hybrid & Enza & October & 0.629 \\
\hline Zeus F1 & Summer & Hybrid & S\&G & October & 0.400 \\
\hline Striker F1 & Summer & Hybrid & Bejo & October & 0.606 \\
\hline Electra & Autumn & Open pollinated & Clause & November & 0.628 \\
\hline Nebraska & Autumn & Open pollinated & Royal Sluis & November & 0.649 \\
\hline Breugel F1 & Autumn & Hybrid & Rijkzwaan & November & 0.576 \\
\hline Tadorna & Autumn & Open pollinated & Enza & November & 0.567 \\
\hline Poribleu & Autumn & Open pollinated & Nickerson-Zwaan & December & 0.759 \\
\hline Alcazar & Autumn & Open pollinated & Rijkzwaan & December & 0.611 \\
\hline Belton F1 & Autumn & Hybrid & Nunhems & January & 0.753 \\
\hline Pretan F1 & Autumn & Hybrid & Nickerson-Zwaan & January & 0.728 \\
\hline Musselburh & Winter & Old land race & D.T. Brown & February & 0.547 \\
\hline Van Limbergen & Winter & Farmer selection & Sint Katelijne Waver & February & 0.542 \\
\hline Buelens & Winter & Farmer selection & Onze Lieve Vrouw Waver & February & 0.509 \\
\hline Coolidge F1 & Winter & Hybrid & Hortiplan & February & 0.524 \\
\hline Apollo F1 & Winter & Hybrid & S\&G & February & 0.485 \\
\hline Artico & Winter & Old land race & IPK & February & 0.354 \\
\hline Farinto & Winter & Open pollinated & Nunhems & February & 0.403 \\
\hline Arkansas & Winter & Open pollinated & Royal Sluis & February & 0.382 \\
\hline Gavia & Winter & Open pollinated & Enza & February & 0.432 \\
\hline Toledo & Winter & Old land race & Thompson \& Morgan & February & 0.476 \\
\hline Uytterhoeven & Winter & Farmer selection & Onze Lieve Vrouw Waver & February & 0.401 \\
\hline Engels & Winter & Farmer selection & Putte & February & 0.389 \\
\hline Vervloet & Winter & Farmer selection & Sint Katelijne Waver & February & 0.361 \\
\hline Harston F1 & Winter & Hybrid & Nunhems & February & 0.516 \\
\hline Fahrenheit F1 & Winter & Hybrid & Royal Sluis & March & 0.393 \\
\hline
\end{tabular}

and only the AA form of vitamin C was analysed. The samples were vortexed for $3 \mathrm{~min}$, then centrifuged for $10 \mathrm{~min}$ at 13,200 rpm at $1{ }^{\circ} \mathrm{C}$. An aliquot $(400 \mu \mathrm{l})$ of the supernatant was transferred directly to HPLC vials and filtered through $0.22 \mu \mathrm{m}$ filters prior to analysis. Standard solutions of L-ascorbic acid (1-1000 $\mu \mathrm{g} \mathrm{ml}^{-1}$ ) were prepared by dilution of a $1 \mathrm{mg} \mathrm{ml}^{-1}$ solution in $5 \%$ MPA containing $5 \mathrm{mM}$ TCEP.

For ORAC and DPPH analysis, extracts were obtained by adding $10 \mathrm{ml}$ of $70 \%$ aqueous ethanol solution $(\mathrm{v} / \mathrm{v})$ to a precisely weighed amount $(500 \mathrm{mg}$ ) of FDLP. This mixture was shaken for $2 \mathrm{~h}$ on an orbital shaker at $300 \mathrm{rpm}$ (shaker type 3500, GFL, Burgwedel, Germany). The homogenates were centrifuged at $4500 \mathrm{rpm}$ for $10 \mathrm{~min}$ (Heraeus Labofuge $400 \mathrm{R}$, Thermo, Aalst, Belgium) and the supernatants were used for the ORAC and DPPH analysis.

Extracts for FRAP analysis were obtained by adding $2 \mathrm{ml}$ of extraction solvent (acetone-water (70:30) with $0.1 \%$ formic acid) to an accurately weighed amount $(100 \mathrm{mg})$ of FDLP. The mixture was vortexed for $15 \mathrm{~s}$ and agitated for $2 \mathrm{~h}$ using a tube rotator (Stuart Scientific blood tube rotator SB1). The homogenates were centrifuged at $4000 \mathrm{rpm}$ for $15 \mathrm{~min}$ (Eppendorf Centrifuge 5810R). An aliquot $(1 \mathrm{ml}$ ) of the supernatant was centrifuged at $13,200 \mathrm{rpm}$ for another 5 min.

\subsection{Determination of total phenolic (TP) Content}

The TP content was determined according to the Folin-Ciocalteu method (Deighton, Brennan, Finn, \& Davies, 2000; Singleton \& Rossi, 1965). However, a drawback with the Folin-Ciocalteu approach is that compounds such as fructose, amino acids and ascorbic acid can contribute to the TP content. Nevertheless, the extraction procedure of Vinson et al. (1998) ensures that the interference of vitamin C with the Folin-Ciocalteu method was not significant. The determination procedure described by Waterman and Mole (1994) was followed with some modifications. An appropriate volume $(0.100 \mathrm{ml})$ of the filtrate was added to $0.5 \mathrm{ml}$ Folin-Ciocalteu reagent (diluted $10 \times$ ) in a volumetric flask of $10 \mathrm{ml}$. After
$6 \mathrm{~min}, 20 \% \mathrm{Na}_{2} \mathrm{CO}_{3}(\mathrm{w} / \mathrm{v}, 1.5 \mathrm{ml})$ was added. Filling up to $10 \mathrm{ml}$ with distilled water, the mixture was shaken and reacted for $2 \mathrm{~h}$ at room temperature in the dark. Absorbance readings were taken against a blank at $740 \mathrm{~nm}$. The standard curve was made using gallic acid standard solution (100-500 $\mathrm{mg} / \mathrm{l}$ ) under the same procedure as above; the same applied to the blank. Results were expressed as milligrams of gallic acid equivalents per gram of dry weight ( $\mathrm{mg} \mathrm{GAE} \mathrm{g}^{-1} \mathrm{dw}$ ).

\subsection{Determination of L-ascorbic acid content}

Total L-ascorbic acid content was determined as described by Hancock, Galpin, and Viola (2000) using an HPLC-photodiode array detection approach. Briefly, $20 \mu \mathrm{l}$ of sample supernatant was injected onto a $300 \times 7.8 \mathrm{~mm}$ ID Coregel $64 \mathrm{H}$ ion exclusion column (Interaction Chromatography, San Jose, CA, USA) with a $4 \times 3 \mathrm{~mm}$ ID carbo- $\mathrm{H}^{+}$guard cartridge (Phenomenex, Macclesfield, UK) maintained at $50{ }^{\circ} \mathrm{C}$. The mobile phase was $8 \mathrm{mM} \mathrm{H}_{2} \mathrm{SO}_{4}$ at $0.6 \mathrm{ml} \mathrm{min}{ }^{-1}$ and AA was detected at $245 \mathrm{~nm}$ using a Gynkotech UVD 340 S diode array detector (Dionex, Camberley, UK). The identification of peak corresponding to AA deduced by their co-elution with standards. Under these conditions, the retention time of AA was $11.70 \mathrm{~min}$.

\subsection{Determination of antioxidant capacity}

\subsubsection{Oxygen radical absorbance capacity (ORAC) assay}

The ORAC procedure established by Prior et al. (2003) and the application note of Ganske and Dell (2006) was followed. Briefly, to each microplate well, $25 \mu$ l Trolox dilution, $25 \mu$ l sample dilution or $25 \mu \mathrm{l} 10 \mathrm{mM}$ phosphate buffer ( $\mathrm{pH}$ 7.4) was pipetted in triplicate for the calibration curve, sample or blank, respectively. One hundred and fifty microlitres of the fluorescein solution (10 nM) was then added to each well. In the next step, the microplate was sealed and incubated at $37^{\circ} \mathrm{C}$ for $30 \mathrm{~min}$. The fluorescence (Ex. $485 \mathrm{~nm}$, Em. $520 \mathrm{~nm}$ ) was subsequently determined every $90 \mathrm{~s}$. After three cycles, $25 \mu \mathrm{l}$ of 2,2'-azobis-2-methyl-propanimidamide 
dihydrochloride (240 mM) was added manually to each well. Fluorescent measurements were taken up for $90 \mathrm{~min}$. Calculations were based on the area under the fluorescence decay curve (AUC) using formula (1).

$\mathrm{AUC}=\mathrm{CT} \times\left[\frac{1}{2}+\left(y_{2}+y_{3}+y_{4}+\cdots y_{60}\right)\right]$

CT-cycle time in min, $y_{n}$-the relative fluorescence unit at cycle $n$.

ORAC values were calculated using a regression equation for a linear regression on the range of $12.5-200 \mu \mathrm{M}$ Trolox standards. The net area under the curve was obtained by subtracting the area under the curve for the blank values from the curves of samples and standards. ORAC values were expressed in $\mu$ moles Trolox Equivalents per gram of dry weight ( $\left.\mu \mathrm{mol} \mathrm{TE} \mathrm{g}^{-1} \mathrm{dw}\right)$.

\subsubsection{2,2-Diphenyl-1-picrylhydrazyl (DPPH) assay}

The procedure used is essentially as described by Hogan, Zhang, Li, Zoecklein, and Zhou (2009) with some modifications. Briefly, an aliquot $(100 \mu \mathrm{l})$ of DPPH solution in ethanol $(0.4 \mathrm{mM})$ was added to the sample extract $(100 \mu \mathrm{l})$ at various concentrations. The absorbance at $520 \mathrm{~nm}$ was determined after a reaction time of $90 \mathrm{~min}$.

DPPH values were calculated using a regression equation for a linear regression on the range of $12.5-200 \mu \mathrm{M}$ Trolox standards. The relative scavenging capacity of the leek extracts were expressed in $\mu$ moles of Trolox Equivalents per gram of dry weight $\left(\mu \mathrm{mol} \mathrm{TE} \mathrm{g}^{-1} \mathrm{dw}\right)$.

\subsubsection{Ferric reducing antioxidant potential (FRAP) assay}

The ferric reducing power of the leek extracts was determined using the method of Deighton et al. (2000). Briefly, a $100 \mu \mathrm{l}$ aliquot of the leek extract (diluted $2 \times$ ) was added to $900 \mu$ of FRAP reagent. Thereafter, the procedure was followed as described. The results were compared with the standard curve using $\mathrm{FeSO}_{4}$ in a range of concentration from $100-1000 \mu \mathrm{M}$. The results were expressed as $\mu$ moles of ferric reducing/antioxidant power of $1 \mathrm{~g}$ freeze-dried leek powder ( $\mu \mathrm{mol} \mathrm{FeSO}_{4} \mathrm{~g}^{-1} \mathrm{dw}$ ).

\subsection{Statistical analysis}

The data are presented as mean \pm standard deviation (SD) of 3 measurements $(n=3)$ and subject to analysis of variance by the SPSS V. 17 statistical programme (SPSS Inc., Chicago, USA). A Pearson correlation test was used to determine the correlations between antioxidant capacity (AC) results, total phenolics and ascorbate content. Differences of $p<0.05$ were considered significant. The Scheffé test was performed to analyse the significant differences between data $(p<0.05)$.

Principal component analysis (PCA) was performed on the results of ORAC, DPPH, FRAP, total phenolics and ascorbate content of the white shaft and the green leaves of the studied leek cultivars using Statistica software (version 10). The PCA was based on correlations and the variances were computed as $S S /(n-1)$. The PCA score plot was used to assess the effect of four aspects (leek part, type, breeding category and origin: Table 3 ) on the five analysed parameters (ORAC, DPPH, FRAP, TP and AA).

\section{Results and discussion}

\subsection{Total phenolic and L-ascorbic acid content}

All of the leek cultivars tested contained significant levels of phenolics (Table 2) and compare favourably against those of the sister species onion (2-30 $\mathrm{mg} \mathrm{GAE} \mathrm{g}^{-1} \mathrm{dw}$ ) and garlic (20 mg $\mathrm{GAE} \mathrm{g}^{-1} \mathrm{dw}$ ) (Gorinstein et al., 2009; Kahkonen et al., 1999). The TP content in the white shaft and green leaves of the 30 leek cultivars
Table 2

Contents of total phenolics and L-ascorbic acid in the white shaft and green leaf extracts of 30 leek cultivars (means of replicates \pm standard deviation).

\begin{tabular}{|c|c|c|c|c|}
\hline \multirow[t]{2}{*}{ Cultivar name } & \multicolumn{2}{|c|}{ 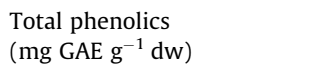 } & \multicolumn{2}{|c|}{$\begin{array}{l}\text { L-Ascorbic acid } \\
\left(\mathrm{mg} \text { L-ascorbic acid } \mathrm{g}^{-1} \mathrm{dw}\right)\end{array}$} \\
\hline & White shaft & Green leaves & White shaft & Green leaves \\
\hline Varna & $7.98 \pm 0.90$ & $7.87 \pm 1.35$ & $0.89 \pm 0.21$ & $2.77 \pm 0.34$ \\
\hline Albana & $7.89 \pm 0.37$ & $9.57 \pm 0.22$ & $2.13 \pm 0.49$ & $8.52 \pm 1.08$ \\
\hline Nelli & $7.41 \pm 0.62$ & $7.98 \pm 0.34$ & $1.26 \pm 0.31$ & $6.33 \pm 0.76$ \\
\hline Elefant & $7.57 \pm 0.59$ & $8.83 \pm 0.30$ & $1.89 \pm 0.41$ & $6.97 \pm 0.57$ \\
\hline Miracle F1 & $6.98 \pm 0.88$ & $7.89 \pm 1.11$ & $1.03 \pm 0.89$ & $4.15 \pm 1.67$ \\
\hline Zeus F1 & $8.67 \pm 0.42$ & $11.30 \pm 1.78$ & $2.70 \pm 0.92$ & $6.74 \pm 2.28$ \\
\hline Striker F1 & $7.95 \pm 0.11$ & $8.89 \pm 0.15$ & $2.04 \pm 0.61$ & $6.75 \pm 0.27$ \\
\hline Electra & $8.34 \pm 0.50$ & $9.15 \pm 0.23$ & n.d. & n.d. \\
\hline Nebraska & $7.57 \pm 0.26$ & $8.34 \pm 0.25$ & n.d. & n.d. \\
\hline Breugel F1 & $7.82 \pm 0.31$ & $8.76 \pm 0.14$ & n.d. & n.d. \\
\hline Tadorna & $5.83 \pm 1.22$ & $6.70 \pm 1.26$ & n.d. & n.d. \\
\hline Poribleu & $5.31 \pm 0.75$ & $5.47 \pm 0.81$ & $1.49 \pm 0.33$ & $3.73 \pm 0.60$ \\
\hline Alcazar & $7.60 \pm 1.14$ & $7.71 \pm 1.54$ & $2.72 \pm 0.30$ & $5.42 \pm 1.71$ \\
\hline Belton F1 & $8.11 \pm 0.15$ & $9.56 \pm 0.37$ & $1.27 \pm 0.19$ & $3.25 \pm 2.82$ \\
\hline Pretan F1 & $7.76 \pm 0.24$ & $9.20 \pm 1.44$ & $3.25 \pm 0.55$ & $3.23 \pm 0.59$ \\
\hline Musselburh & $8.04 \pm 0.29$ & $9.52 \pm 0.39$ & $1.44 \pm 0.50$ & $4.25 \pm 0.64$ \\
\hline Van Limbergen & $11.29 \pm 0.19$ & $11.23 \pm 1.22$ & $2.55 \pm 0.48$ & $5.01 \pm 1.75$ \\
\hline Buelens & $7.41 \pm 0.32$ & $8.57 \pm 0.36$ & $1.80 \pm 0.48$ & $4.71 \pm 0.94$ \\
\hline Coolidge F1 & $7.79 \pm 0.81$ & $9.08 \pm 0.67$ & $2.07 \pm 0.83$ & $4.09 \pm 0.83$ \\
\hline Apollo F1 & $7.79 \pm 0.42$ & $8.87 \pm 0.63$ & $1.85 \pm 0.51$ & $3.69 \pm 0.38$ \\
\hline Artico & $9.14 \pm 0.29$ & $10.56 \pm 0.14$ & $1.05 \pm 0.27$ & $5.14 \pm 0.78$ \\
\hline Farinto & $9.07 \pm 0.69$ & $10.50 \pm 1.09$ & $1.29 \pm 0.26$ & $3.58 \pm 0.64$ \\
\hline Arkansas & $8.64 \pm 0.53$ & $9.95 \pm 0.12$ & $1.64 \pm 0.23$ & $4.40 \pm 0.12$ \\
\hline Gavia & $8.71 \pm 0.12$ & $9.64 \pm 0.52$ & $2.13 \pm 0.47$ & $6.74 \pm 0.25$ \\
\hline Toledo & $13.96 \pm 0.71$ & $15.14 \pm 0.23$ & $1.75 \pm 0.59$ & $6.37 \pm 0.45$ \\
\hline Uyterhoeven & $7.73 \pm 0.09$ & $8.74 \pm 0.58$ & $1.64 \pm 0.70$ & $7.48 \pm 1.05$ \\
\hline Engels & $8.50 \pm 0.45$ & $10.29 \pm 0.45$ & $1.51 \pm 0.65$ & $4.51 \pm 1.13$ \\
\hline Vervloet & $7.91 \pm 1.48$ & $9.67 \pm 1.73$ & $1.59 \pm 0.15$ & $6.36 \pm 1.61$ \\
\hline Harston F1 & $7.33 \pm 0.68$ & $8.21 \pm 1.05$ & $1.66 \pm 0.40$ & $5.29 \pm 0.83$ \\
\hline Fahrenheit F1 & $9.58 \pm 0.13$ & $9.02 \pm 0.69$ & $3.55 \pm 0.82$ & $7.96 \pm 0.50$ \\
\hline
\end{tabular}

n.d.: Not detected.

Table 3

Pearson's correlation coefficients of the antioxidant activities, total phenol and L-ascorbic acid content of the white shaft and green leaves of 30 leek cultivars.

\begin{tabular}{llllll}
\hline & Part & FRAP & DPPH & $\begin{array}{l}\text { Total } \\
\text { phenolics }\end{array}$ & $\begin{array}{l}\text { L-Ascorbic } \\
\text { acid }\end{array}$ \\
\hline ORAC & White shaft & $0.783^{*}$ & $0.649^{*}$ & $0.307^{*}$ & $0.377^{*}$ \\
& Green leaves & 0.125 & 0.009 & $0.275^{*}$ & 0.114 \\
FRAP & White shaft & & $0.649^{*}$ & $0.253^{*}$ & $0.684^{*}$ \\
& Green leaves & & 0.039 & $0.213^{*}$ & $0.580^{*}$ \\
DPPH & White shaft & & & 0.117 & $0.254^{*}$ \\
& Green leaves & & & 0.176 & 0.201 \\
Total phenolics & White shaft & & & & $0.242^{*}$ \\
& Green leaves & & & & $0.220^{*}$ \\
\hline
\end{tabular}

Significant correlation at $p<0.05$

varied from 5 to $14 \mathrm{mg} \mathrm{GAE} \mathrm{g}^{-1} \mathrm{dw}$ and from 5 to $15 \mathrm{mg}$ GAE $\mathrm{g}^{-1} \mathrm{dw}$, respectively.

The highest TP content was observed from the white shaft extracts of the cultivars Toledo, Van Limbergen and Artico, and from the extracts of the green leaves of the cultivars Toledo, Zeus F1 and Van Limbergen. The cultivar Toledo showed a significantly higher TP content in the white shaft and green leaves in comparison with the other cultivars. Among the 30 leek cultivars, the whole leek plant of the cultivar Toledo rated highest for mean TP content (14 $\mathrm{mg} \mathrm{GAE} \mathrm{g}^{-1} \mathrm{dw}$ ). Proteggente et al. (2002) reported a TP content in the whole leek plant of $22 \mathrm{mg} \mathrm{GAE} 100 \mathrm{~g}^{-1}$ of fresh weight (fw) and Vandekinderen et al. (2009) a content of 38-56 mg GAE $100 \mathrm{~g}^{-1} \mathrm{fw}$. Our results are expressed in $\mathrm{g}^{-1} \mathrm{dw}$, however, a precise recalculation to $100 \mathrm{~g}^{-1} \mathrm{fw}$ is not possible, because the water content was not determined for all the samples. For the samples that were analysed for their water content, the mean water content 
was $87 \%$ in the white shaft and $85 \%$ in the green leaves, resulting in a mean water content of $86 \%$ in the whole leek plant. Using this conversion factor to convert our results to $\mathrm{g}^{-1} \mathrm{fw}$, the TP contents reported by Proteggente et al. (2002) and Vandekinderen et al. (2009) are much lower than found for the cultivars tested here (74.87-196.84 mg GAE $100 \mathrm{~g}^{-1} \mathrm{fw}$ in the white shaft and 77.13$213.47 \mathrm{mg}$ GAE $100 \mathrm{~g}^{-1} \mathrm{fw}$ in the green leaves). These variations could be due to differences among cultivars, growing seasons, agricultural practices and variations in applied total phenolic determinations assays.

The U.S. Department of Agriculture (U.S. Department of Agriculture, 2010) measured the TP content of 277 selected foods. They reported a TP content of $47 \mathrm{mg} \mathrm{GAE} 100 \mathrm{~g}^{-1} \mathrm{fw}$ in the bulb and lower leaves of leek. Again, this TP content is lower than our results. The TP content of leek reported by the USDA was in the same range of iceberg lettuce ( $50 \mathrm{mg} \mathrm{GAE} 100 \mathrm{~g}^{-1} \mathrm{fw}$ ) and celery (42 mg GAE 100 $\mathrm{g}^{-1} \mathrm{fw}$ ), higher than the TP content of raw carrots (35 mg GAE 100 $\mathrm{g}^{-1} \mathrm{fw}$ ), raw cucumber (22 mg GAE $100 \mathrm{~g}^{-1} \mathrm{fw}$ ) and raw onions (23 mg GAE $100 \mathrm{~g}^{-1} \mathrm{fw}$ ), but lower than the TP content in raw broccoli (316 mg GAE $100 \mathrm{~g}^{-1} \mathrm{fw}$ ), raw cabbage (202 mg GAE $100 \mathrm{~g}^{-1} \mathrm{fw}$ ) and raw spinach (205 mg GAE $100 \mathrm{~g}^{-1} \mathrm{fw}$ ).

The leek cultivars Albana, Elefant, Striker F1, Nebraska, Breugel F1, Belton F1, Musselburh, Buelens, Artico, Arkansas, Gavia, Uyterhoeven, Engels and Kenton F1 showed a significantly higher TP content in the green leaves in comparison with the TP content measured in the white shaft. For the other cultivars, there was no significant difference. These results are perhaps in contrast with our expectation that the green leaves in all cases would contain a significantly higher amount of total phenolics in comparison with the white part. Several reports identify a correlation between enhanced polyphenol production and exposure to UV-B radiation (sunlight) in St. John's wort (Germ, Stibilj, Kreft, Gaberscik, \& Kreft, 2010), barley (Kaspar, Matros, \& Mock, 2010) and Arabidopsis (Jordan, James, \& Mackerness, 1998). Because the green leaves grow above the ground, in contrast with the white shaft, they receive more sunlight radiation and thus, would contain higher TP content. The explanation for why this is not true for some of our analysed leek cultivars could be attributed to other environmental factors and stress conditions that the white shaft can experience (Michalak, 2006). Besides UV light exposure, insect and microorganism pressure, low temperatures and low nutrient conditions correlates with the synthesis of phenolics and can be responsible for a difference in TP content for the 30 leek cultivars (Duval, Shetty, \& Thomas, 1999; Michalak, 2006). Environmental factors are not the only possible explanation for these differences; the method employed to analyse the polyphenols can also result in varying results. The Folin-Ciocalteu method may also determine other reducing compounds as reducing sugars, which are present in leek. These sugars can interfere in the Folin method if they are present in high concentrations (Vinson, Proch, \& Bose, 2001). In addition, the Folin-Ciocalteu reagent also reacts with some nitrogen compounds as amino acids (e.g., tyrosine and tryptophan) and amines (Ikawa, Schaper, Dollard, \& Sasner, 2003; Peterson, 1979).

The ascorbate content in the white shaft and green leaves varied from 0.89 to $3.55 \mathrm{mg} \mathrm{AA} \mathrm{g}^{-1} \mathrm{dw}$ and from 2.77 to $8.52 \mathrm{mg} \mathrm{AA} \mathrm{g}^{-1}$ $\mathrm{dw}$, respectively (Table 2 ). In most of the cases the ascorbate levels in the green leaves were significantly higher than those measured in the white shaft, except for the cultivars Alcazar, Belton F1, Pre$\tan \mathrm{F} 1$ and the farmer selection of Van Limbergen, where no significant difference was measured. For some cultivars no detectable ascorbate even appeared to be present using the method described (Electra, Nebraska, Breugel F1 and Tadorna,). The highest total Lascorbic acid content was observed in the white shaft extracts from Fahrenheit F1, Pretan F1 and Alcazar, and in the green leaf extracts of Albana, Fahrenheit F1 and Uyterhoeven. Of all cultivars tested, the whole leek plant of the cultivar Fahrenheit F1 contained the highest mean ascorbate content (5.54 mg ascorbate $\mathrm{g}^{-1} \mathrm{dw}$ ). Our results of L-ascorbic acid for the white shaft of leek were in the same range as reported by Lundegardh et al. (2008) (1.6-2.3 $\mathrm{mg}$ ascorbate $\mathrm{g}^{-1} \mathrm{dw}$ ). Proteggente et al. (2002) reported a total vitamin C content in leek of $16 \mathrm{mg} 100 \mathrm{~g}^{-1} \mathrm{fw}$ and Vandekinderen et al. (2009) reported a content of $8.26-15.78 \mathrm{mg}$ ascorbate $100 \mathrm{~g}^{-1} \mathrm{fw}$, which is in the same range as our results using the dry weight converter (12-50 mg ascorbate $100 \mathrm{~g}^{-1} \mathrm{fw}$ in the white shaft and 39-120 mg ascorbate $100 \mathrm{~g}^{-1} \mathrm{fw}$ in the green leaves).

Unlike the polyphenols, the vitamin C content of onion (1889 mg $100 \mathrm{~g}^{-1} \mathrm{dw}$ ) reported by Mota, Luciano, Dias, Barroca, and Guine (2010) was higher than found in leek.

Based on various experiments, Lester (2006) has reported that vegetable and fruit size majorly affects the concentration of available phytonutrients such as $\beta$-carotene, ascorbic acid and folic acid. In general, ascorbic acid decreases with increasing size.

In our results, we found a significant but weak negative correlation for the green leaves $(r=-0.44, p=0.05)$ between the average weight of the leek plant for each cultivar (Table 1) and its ascorbate content.

\subsection{Antioxidant capacity}

The ORAC values (Fig. 1) for the white shaft and green leaves covered significant ranges; $27-88$ and $82-135 \mu \mathrm{mol} \mathrm{TE} \mathrm{g}{ }^{-1} \mathrm{dw}$, respectively. The highest ORAC value was observed in the white shaft extracts from the leek cultivars Pretan F1, Uyterhoeven and

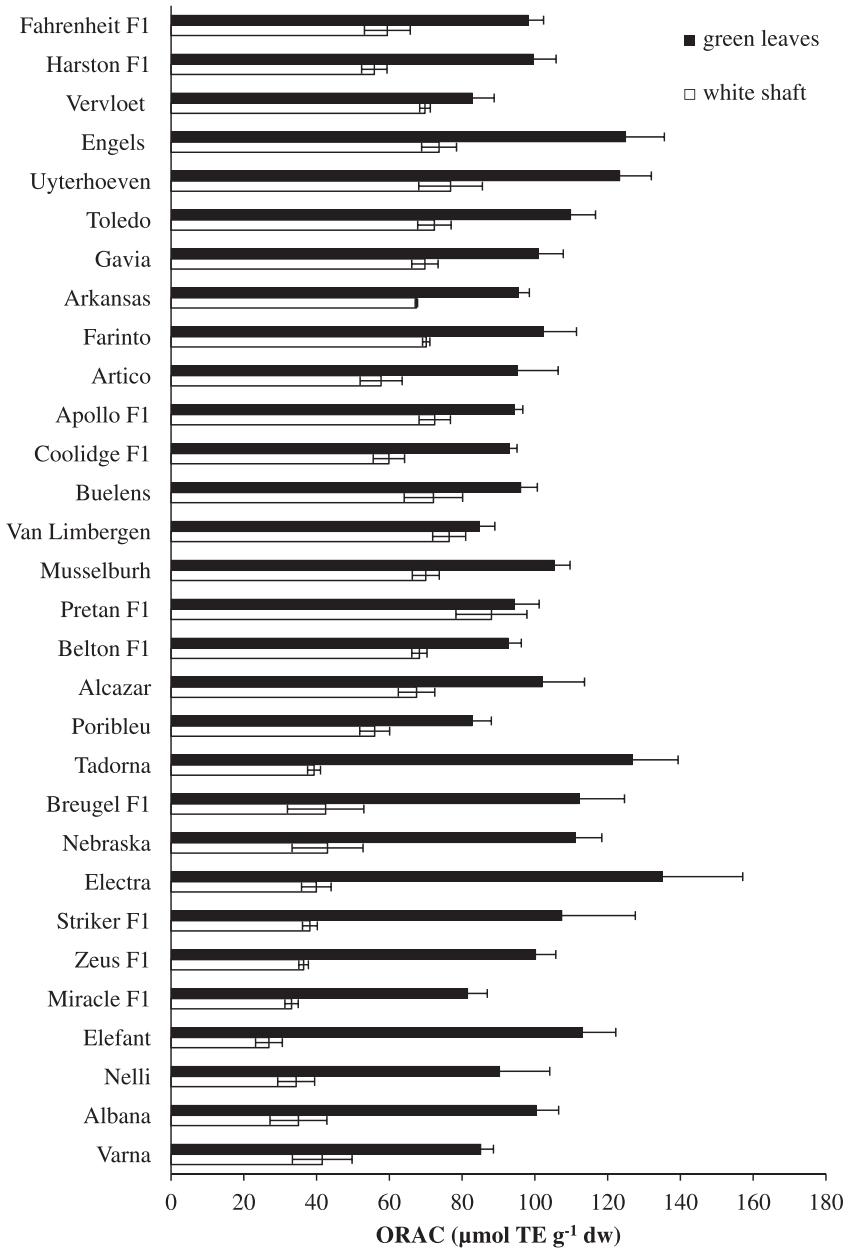

Fig. 1. The ORAC-derived antioxidant capacities of the leek cultivars. 
Van Limbergen and from the green leaf extracts of Electra, Tadorna and Engels. Among all cultivars tested, the whole leek plant of cultivar Uyterhoeven contained the highest mean ORAC value $\left(97.78 \mu \mathrm{mol} \mathrm{TE}^{-1} \mathrm{dw}\right)$. In all cases the ORAC values for the green leaves were significantly higher than those measured in the white shaft of leek, except for the cultivar Pretan F1, where no significant difference was measured.

The U.S. Department of Agriculture (2010) reported a total ORAC value of $569 \mu \mathrm{mol} \mathrm{TE} 100 \mathrm{~g}^{-1} \mathrm{fw}$ in the bulb and lower leaves of leek. Assuming a moisture content of $86 \%$, the ORAC values, reported by the USDA are in the range of our grown leek plants, 379$1242 \mu \mathrm{mol} \mathrm{TE} 100 \mathrm{~g}^{-1} \mathrm{fw}$ in the white shaft and 1150-1904 mg TE $100 \mathrm{~g}^{-1} \mathrm{fw}$ in the green leaves.

The ORAC value for leek as reported by the USDA was in the same range as raw cabbage ( $\left.529 \mu \mathrm{mol} \mathrm{TE} 100 \mathrm{~g}^{-1} \mathrm{fw}\right)$, raw pumpkin ( $\left.483 \mu \mathrm{mol} \mathrm{TE} 100 \mathrm{~g}^{-1} \mathrm{fw}\right)$ and celery $\left(552 \mu \mathrm{mol} \mathrm{TE} 100 \mathrm{~g}^{-1} \mathrm{fw}\right)$, higher than the ORAC of raw cucumber $\left(140 \mu \mathrm{mol} \mathrm{TE} 100 \mathrm{~g}^{-1} \mathrm{fw}\right)$, raw tomatoes $\left(387 \mu \mathrm{mol}\right.$ TE $\left.100 \mathrm{~g}^{-1} \mathrm{fw}\right)$ and iceberg lettuce ( $438 \mu \mathrm{mol} \mathrm{TE} 100 \mathrm{~g}^{-1} \mathrm{fw}$ ) but lower than the ORAC in raw broccoli $\left(1510 \mu \mathrm{mol} \mathrm{TE} 100 \mathrm{~g}^{-1} \mathrm{fw}\right)$, raw garlic $\left(5708 \mu \mathrm{mol} \mathrm{TE} 100 \mathrm{~g}^{-1} \mathrm{fw}\right)$, onion $\left(913 \mu \mathrm{mol} \mathrm{TE} 100 \mathrm{~g}^{-1} \mathrm{fw}\right)$ and raw spinach $(1513 \mu \mathrm{mol} \mathrm{TE}$ $\left.100 \mathrm{~g}^{-1} \mathrm{fw}\right)$. Ou, Huang, Hampsch-Woodill, Flanagan, and Deemer (2002) reported an ORAC value of 85 and $143 \mu \mathrm{mol} \mathrm{TE} \mathrm{g}^{-1} \mathrm{dw}$ in white onion and purple onion, respectively.

Similarly, the associated DPPH values (data not shown) of these

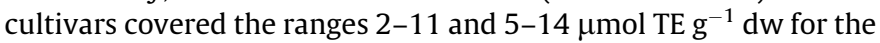
white shaft and green leaves, respectively. The highest DPPH value was observed from the white shaft extracts from Pretan F1, Nebraska and Apollo F1 and from the green leaf extracts of Gavia, Artico and Pretan F1. Among all the cultivars tested, the whole leek plant of the cultivar Pretan F1 contained the highest mean DDPH value $\left(10.88 \mu \mathrm{mol} \mathrm{TE}^{-1} \mathrm{dw}\right)$. Generally, the DPPH values for the green leaves were significantly higher than those measured in the white shaft of leek, except for the cultivars Miracle F1, Breugel F1, Poribleu, Pretan F1, Buelens, Apollo F1, Farinto, Arkansas, Kenton F1 and Fahrenheit F1, where no significant difference was measured. Gorinstein et al. (2009) investigated the antiradical activity against the DPPH radical for the Allium species garlic, red, white and yellow onion: $7 \mu \mathrm{M} \mathrm{TE} \mathrm{g}^{-1} \mathrm{dw}, 22 \mu \mathrm{M} \mathrm{TE} \mathrm{g}^{-1} \mathrm{dw}, 21$ and $20 \mu \mathrm{M} \mathrm{TE} \mathrm{g}^{-1} \mathrm{dw}$, respectively.

The FRAP values (data not shown) ranged between 3-18 and 14-37 $\mu \mathrm{mol} \mathrm{FeSO}{ }_{4} \mathrm{~g}^{-1} \mathrm{dw}$ for the white shafts and green leaves, respectively. The highest FRAP value was observed from the white shaft extracts from Fahrenheit F1, Pretan F1 and Apollo F1 and from the green leaf extracts of Vervloet, Fahrenheit F1 and Zeus F1. In general, the whole leek plant of the cultivar Fahrenheit F1 contained the highest mean FRAP value $\left(26 \mu \mathrm{mol} \mathrm{FeSO} \mathrm{g}^{-1} \mathrm{dw}\right)$. With the exception of Fahrenheit F1, the FRAP values for the green leaves were significantly higher than those measured in the white shaft of leek. This concurs with Nencini, Menchiari, Franchi, and Micheli (2011) who reported similar conclusions when analysing the bulb, leaves and flowers of four Allium species (A. neopolitanum Cyr., A. Roseum L., A. subhirsutum L. and A. sativum L.). Halvorsen et al. (2002) analysed the total antioxidants in a variety of dietary plants by the reduction of $\mathrm{Fe}^{3+}-\mathrm{Fe}^{2+}$. From this study, it was clear that leek contained more antioxidants than tomato, cauliflower, and cucumber, but less than spinach, broccoli and red cabbage.

The DPPH, FRAP and ORAC assays are the most widely used methods for determining antioxidant capacity in vitro. Each antioxidant in a complex sample has a different activity pattern in each method, resulting in different data for each assay. Therefore, to ensure that a sample exhibits significant higher antioxidant capacity, several methods and standards should be used and their results compared (Perez-Jimenez et al., 2008; Prior, Wu, \& Schaich, 2005; Serrano et al., 2007; Tafulo, Queiros, Delerue-Matos, \& Sales, 2010).
The ORAC assay is the only method that takes free radical action to completion and uses the AUC technique for quantification. It combines both inhibition percentage and the length of inhibition time of the free radical action by antioxidants into a single value (Prior \& Cao, 1999). The ORAC assay is considered to be a preferable method because of its biological relevance to the in vivo antioxidant efficacy (Gu, House, Wu, Ou, \& Prior, 2006).

The DPPH assay is simple to use, but has some disadvantages that limit its application. Many antioxidants that react rapidly with peroxide radicals may have a very slow reaction to DPPH or may even be inert to it (Huang et al., 2005; Kurechi, Kikugawa, \& Kato, 1980).

FRAP is the only assay that directly measures antioxidants in a sample. The other assays are indirect because they measure the inhibition of reactive species (free radicals) generated in the reaction mixture, and these results also depend strongly on the type of reactive species used. The FRAP assay uses antioxidants as reductants in a redox-linked colorimetric reaction (Halvorsen et al. 2002). One disadvantage with the FRAP assay is that this assay does not react with thiols, because the reduction potential for thiols are generally below that of $\mathrm{Fe}^{3+} / \mathrm{Fe}^{2+}$ half-reaction. Vegetables from the Alliaceae family contain a high number of sulphur-containing compounds. In the study of Cao, Alessio, and Cutler (1993) garlic had the highest antioxidant activity, analysed by the ORAC assay, while Halvorsen et al. (2002) showed that it had a very low ferric reducing potential.

In general, the white shaft of leek contained on average $8 \mathrm{mg}$ $\mathrm{GAE} \mathrm{g}^{-1} \mathrm{dw}, 2 \mathrm{mg}$ L-ascorbic acid $\mathrm{g}^{-1} \mathrm{dw}$, and had an antioxidant activity of $57 \mu \mathrm{mol} \mathrm{TE} \mathrm{g}^{-1} \mathrm{dw}$ (ORAC), $9 \mu \mathrm{mol} \mathrm{Fe}_{2} \mathrm{SO}_{4} \mathrm{~g}^{-1} \mathrm{dw}$ (FRAP) and $6 \mu \mathrm{mol} \mathrm{TE} \mathrm{g}^{-1} \mathrm{dw}$ (DPPH). The green leaves contained in average $9 \mathrm{mg} \mathrm{GAE} \mathrm{g}^{-1} \mathrm{dw}, 5 \mathrm{mg}^{\mathrm{L}}$-ascorbic acid $\mathrm{g}^{-1} \mathrm{dw}$, and had an antioxidant activity of $101 \mu \mathrm{mol} \mathrm{TE} \mathrm{g}^{-1} \mathrm{dw}$ (ORAC), $27 \mu \mathrm{mol} \mathrm{Fe} \mathrm{SO}_{4} \mathrm{~g}^{-1} \mathrm{dw}$ (FRAP) and $9 \mu \mathrm{mol} \mathrm{TE} \mathrm{g}^{-1} \mathrm{dw}$ (DPPH).

Among the 30 leek cultivars, the cultivar Pretan F1 gave the best results for the antioxidant capacity in the white shaft and green leaves of the leek cultivars, followed by Uyterhoeven and Apollo F1. The cultivars Toledo, Fahrenheit and Van Limbergen contained the highest amount of total phenolics and ascorbate.

\subsection{Correlation}

To explore the influence of the gross phytochemical constituents on antioxidant capacity in leek extracts, we determined the correlation between the antioxidant capacity and antioxidant substances (ascorbic acid and total phenolics). The correlation coefficients for the white shaft and green leaves are shown in Table 3.

Results of the ORAC and FRAP assay were positive but weakly correlated to the phenolic compound concentration $(r=0.307$ $(p<0.05)$ and $r=0.253(p<0.05)$, respectively), and the results of the three AC assays were all significantly correlated with the Lascorbic acid content in the white shaft of leek (FRAP: $r=0.684$, ORAC: $r=0.377$, DPPH: $r=0.254, p<0.05$ ). A positive and stronger correlation was detected between the results of the three antioxidant capacity assays done on the extracts of the white shaft of leek. The highest correlation was found between the ORAC and FRAP $(r=0.783: p<0.05)$, followed by ORAC vs. DPPH $(r=0.649: p<$ $0.05)$ and FRAP vs. DPPH $(r=0.649: p<0.05)$. Thaipong et al. (2006) also detected a high correlation among DPPH, ORAC and FRAP in guava fruits.

Results of the ORAC and FRAP assay were significantly correlated to the phenolic compound concentration in the green leaves of leek: $r=0.275(p<0.05)$ and $r=0.213(p<0.05)$, respectively. Results of the FRAP assay and TP content were significantly correlated to the L-ascorbic acid concentration in the green leaves of leek, $r=0.580$ $(p<0.05)$ and $r=0.220(p<0.05)$ respectively. No statistically significant correlation was detected between the results of the three 
antioxidant capacity assays done on the extracts of the green leaves of leek.

In conclusion, the antioxidant capacity of leek extracts measured by the three AC assays appears to be influenced by the AA levels in the white shaft of leek plant, but only the results of the FRAP and ORAC assays could be correlated to the TP content of the whole plant.

\subsection{Principal component analysis (PCA)}

PCA was applied on the whole data set of the 30 leek cultivars. The loadings, eigenvalues and percentage of cumulative variance are shown in Table 4 . The dimensionality of the data was reduced from 5 partially correlated variables to 2 uncorrelated principal components, PC1 and PC2, accounting for $80.3 \%$ of the variation. The absolute value of the loadings is an indicator of the participation of the analysed parameters in the PCs (Helena et al., 2000). PC1 correlates inversely with the variables in the decreasing order FRAP $>$ ORAC $>$ DPPH $>$ ascorbate $>$ total phenolics, whilst PC2 highly correlates with the total phenolics. The graphic representation of the scores and loadings is shown in Fig. 2a and b, respectively. The relationships between the analysed parameters and also similarities or differences between the white shaft and green leaves of the 30 cultivars can be detected through investigation of this PCA plot. FRAP, ORAC and DPPH were the features with negative loadings on PC1 and PC2. These parameters were significantly correlated with each other which could be seen from the PCA plot (Fig. 2) and the Pearson correlation coefficients (Table 3). Total phenolics and ascorbate were the features with negative loadings on PC1

Table 4

Loadings, eigenvalues and percentage of cumulative variance for the first 2 principa components of the data from the white shaft and green leaves of 30 leek cultivars.

\begin{tabular}{lll}
\hline Variable & PC1 & PC2 \\
\hline Total phenolics & -0.57 & 0.81 \\
Ascorbate & -0.81 & 0.04 \\
ORAC & -0.87 & -0.19 \\
FRAP & -0.93 & -0.14 \\
DPPH & -0.81 & -0.23 \\
Eigenvalues & 3.25 & 0.77 \\
\% Cumulative variance & 64.91 & 80.27 \\
\hline
\end{tabular}

and positive loadings on PC2. These two parameters were also significantly but weakly correlated what could be seen from the PCA plot (Fig. 2) and the Pearson correlation coefficients (Table 3).

The PCA plot convincingly segregated the white shaft and the green leaves on the basis of the ascorbate content, AC and to a lesser extent the TP content. More specifically, the green leaves of the 30 leek cultivars possesses a higher $A C$ and a higher content of ascorbate and TP. Although, the green leaves of Miracle F1 were located close to the white shaft cluster, whilst the white shaft of Pre$\tan \mathrm{F} 1$ was located in the green leaves cluster.

The white shaft and green leaves of cultivar Toledo, an old landrace, were clearly differentiated from the other cultivars by their higher TP content. The results of the white shaft and green leaves of the cultivars Poribleu and Tadorna, two open pollinated cultivars, were separated from the other cultivars as a result of their lower TP content. The green part of Zeus F1, Van Limbergen and Farinto is clearly different from the green leaves of the other cultivars.

The score plot (Fig. 2a) showed a clear segregation of the summer, autumn and winter leek types. The white shaft of cultivar Musselburh, a winter type, overlapped with the autumn types, while cultivar Alcazar, an autumn type overlapped with the winter types. Loadings of all analysed parameters indicated that the leek cultivars with high L-ascorbic acid and TP content are situated in the upper, left side of the scores plot and the cultivars with high antioxidant capacity in the bottom, left side. More specific for the white part, the summer cultivars contained a lower AC in comparison with the autumn and winter cultivars. The autumn cultivars, on the other hand, contained a lower TP and ascorbate content in comparison with the summer and winter cultivars. In general, the white shaft of the winter leek cultivars gave the highest results for the TP and ascorbate content and the AC values. The data of the green leaves, on the other hand, revealed that the summer and winter cultivars gave the highest results for the TP and ascorbate content and the AC values.

Genetic background can play a role in the antioxidant content, but also abiotic factors (temperature, water, radiation), biotic factors (pathogens) and man-related factors (pollution), to which the plants are subjected (Mazid, Khan, \& Mohammad, 2011). These factors may partly explain the different accumulation patterns of health-related compounds between the summer, autumn and winter leek, harvested in the respectively period. Stress conditions, such as cold day/night temperature, could be the reason for the

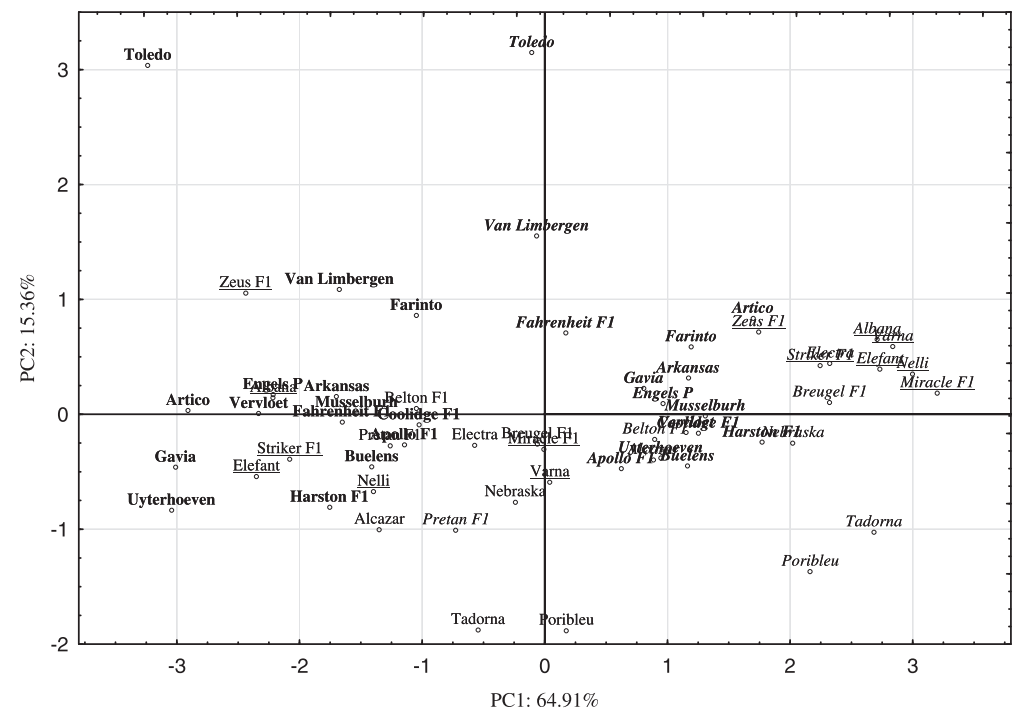

(a)

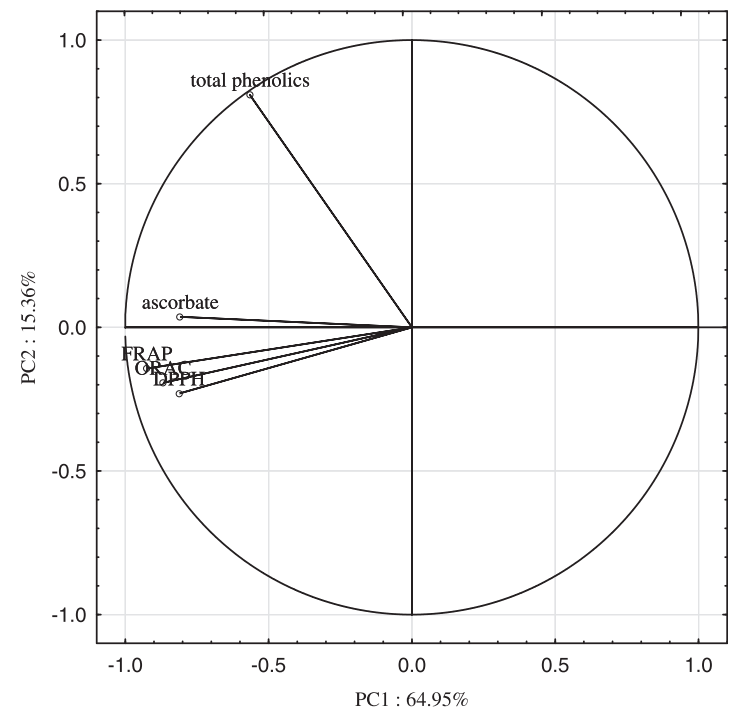

(b)

Fig. 2. PCA plot of the scores (a) and loadings (b) of the white shaft and green leaves of 30 leek cultivars with summer, autumn and winter types, 
higher antioxidant values in the winter types. Boo, Heo, Gorinstein, and Chon (2011) reported an increase of the antioxidant capacity when lettuce was grown at low day/night temperatures in comparison with growth at higher temperatures.

Exposure to increased UV-B light could be the reason for the high health-related compounds in the leaves of the summer types. Notably, all studies dealing with high UV stress found an increase in antioxidants, and especially phenolics concentration in various crops (Wang \& Frei, 2011). Flavonoids, one of the largest classes of plant phenolic, protect plant cells from UV-B radiation because they accumulate in epidermal layers of leaves and stems and absorb light strongly in the UV-B region while letting visible (PAR) wavelengths throughout uninterrupted (Lake, Field, Davey, Beerling, \& Lomax, 2009). In addition, exposure of plants to increased UV-B light has demonstrated to increase the synthesis of flavones and flavonols. Rodrigues, Perez-Gregorio, Garcia-Falcon, SimalGandara, and Almeida (2011) observed higher levels of flavonols in onion samples grown in years with higher solar radiation and lower rainfall during the growing season. It is known that cherry tomato plants grown under high light conditions accumulated approximately double their normal content in soluble phenols than plants grown under low light intensity (Wilkens, Spoerke, \& Stamp, 1996).

Compared to phenolics, fewer studies have investigated the effects of stress on ascorbate concentrations in harvested products, and the results were more contradictory, which may be explained by the complexity of the ascorbate metabolism in plants (Wang \& Frei, 2011).

It can be concluded that the autumn leek types are probably less exposed to stress conditions and contain by result less secondary metabolites than the summer and winter types.

The leek cultivars could be differentiated by PCA on the basis of the leek part and leek type, but they could not be segregated with PCA on the basis of breeding strategy (hybrids, open pollinated cultivars, farmer selections and old land races) and seed company (PCA data not shown).

\section{Conclusions}

Statistically significant differences were observed among the leek cultivars in terms of antioxidant capacity, TP and ascorbate content. The antioxidant capacity of the leek extracts was influenced by the part and type of cultivar to a large extent, whilst the manner of breeding and seed company had no influence on the antioxidant properties. The green leaves of the 30 leek cultivars possess stronger antioxidant properties than the white shaft. The white shaft of the summer cultivars contained a lower AC in comparison with the autumn and winter cultivars. The autumn cultivars, on the other hand, contained a lower TP and ascorbate content in comparison with the summer and winter cultivars. In general, the white shaft of the winter cultivars contained the highest TP and ascorbate content and the strongest AC. The green leaves of the summer and winter cultivars contained higher antioxidant properties in comparison with the green leaves of the autumn cultivars. This can be explained by their genetic background, but stress factors such as temperature, solar radiation, and pathogens to which the plants are subjected, may also partly explain the different accumulation patterns of health-related compounds between the summer, autumn and winter leek. However, an understanding of the influence of environmental factors and their interactions with agricultural practices in relation to antioxidants present in leek is still lacking. Further studies will help to elucidate effects of genotype, growth stage and production environment on antioxidant capacities and may lead to recommended practises to maximise the antioxidant properties of leek. For example, we are currently specifically investigating the effect of harvest time on the content of health-related compounds in a selected set of leek F1 hybrids.

\section{Acknowledgements}

Research funded by a Ph.D. Grant from the Agency for Innovation by Science and Technology (IWT). Derek Stewart acknowledges funding from the Scottish Government.

\section{Appendix A. Supplementary data}

Supplementary data associated with this article can be found, in the online version, at http://dx.doi.org/10.1016/j.foodchem.2012. 02.159 .

\section{References}

Ames, B. N., Shigenaga, M. K., \& Hagen, T. M. (1993). Oxidants, antioxidants, and the degenerative diseases of aging. Proceedings of the National Academy of Sciences of the United States of America, 90, 7915-7922.

Augusti, K. T. Therapeutic and medicinal values of onions and garlic. In Brewster, J. L., Rabinowitch, H. D. (Eds.), 1990. Onions and Allied Crops (vol. III, pp. 93-108) Biochemistry, Food Science and Minor Crops: CRC Press.

Boffetta, P., Couto, E., Wichmann, J., Ferrari, P., Trichopoulos, D., Bueno-de-Mesquita, H. B., et al. (2010). Fruit and vegetable intake and overall cancer risk in the european prospective investigation into cancer and nutrition (EPIC). Journal of the National Cancer Institute, 102, 529-537.

Boo, H. O., Heo, B. G., Gorinstein, S., \& Chon, S. U. (2011). Positive effects of temperature and growth conditions on enzymatic and antioxidant status in lettuce plants. Plant Science, 181, 479-484.

Burt, J. (2011). Growing leeks in Western Australia. Farmnote, 52.

Cao, G. H., Alessio, H. M., \& Cutler, R. G. (1993). Oxygen-radical absorbency capacity assay for antioxidants. Free Radical Biology and Medicine, 14, 303-311.

Carson, J. (1987). Chemistry and biological properties of onions and garlic. Food Reviews International, 3, 71-103.

Chu, Y. H., Chang, C. L., \& Hsu, H. F. (2000). Flavonoid content of several vegetables and their antioxidant activity. Journal of the Science of Food and Agriculture, 80 561-566.

Dai, D. F., \& Rabinovitch, P. S. (2009). Cardiac aging in mice and humans: The role of mitochondrial oxidative stress. Trends in Cardiovascular Medicine, 19, 213-220.

De Clercq, H., \& Van Bockstaele, E. (2002). Allium Crop Science. recent advances. In Rabinowith H. D., Currah, L. (Eds.), Leek: Advances in agronomy and breeding. CABI publishing (chap. 18).

De Clercq, H., Peusens, D., Roldan-Ruiz, I., \& Van Bockstaele, E. (2003). Causal relationships between inbreeding, seed characteristics and plant performance in leek (Allium porrum L.). Euphytica, 134, 103-115.

Deighton, N., Brennan, R., Finn, C., \& Davies, H. V. (2000). Antioxidant properties of domesticated and wild Rubus species. Journal of the Science of Food and Agriculture, 80, 1307-1313.

Duval, B., Shetty, K., \& Thomas, W. H. (1999). Phenolic compounds and antioxidant properties in the snow alga Chlamydomonas nivalis after exposure to UV light Journal of Applied Phycology, 11, 559-566.

Eurostat (2010). Agricultural statistics - Fruits and vegetables (annual data) Publications Office of the European Community.

Evans, P., \& Halliwell, B. (2001). Micronutrients: Oxidant/antioxidant status. British Journal of Nutrition, 85, S67-S74.

Fattorusso, E., Lanzotti, V., Taglialatela-Scafati, O., \& Cicala, C. (2001). The flavonoids of leek, Allium porrum. Phytochemistry, 57, 565-569.

Gandini, S., Merzenich, H., Robertson, C., \& Boyle, P. (2000). Meta-analysis of studies on breast cancer risk and diet: The role of fruit and vegetable consumption and the intake of associated micronutrients. European Journal of Cancer, 36 636-646.

Ganske, F., \& Dell, E. J. (2006). ORAC assay on the FLUOstar OPTIMA to Determine Antioxidant Capacity - BMG LABTECH. Application note 148.

Germ, M., Stibilj, V., Kreft, S., Gaberscik, A., \& Kreft, I. (2010). Flavonoid, tannin and hypericin concentrations in the leaves of St. John's wort (Hypericum perforatum L.) are affected by UV-B radiation levels. Food Chemistry, 122, 471-474.

Gorinstein, S., Park, Y. S., Heo, B. G., Namiesnik, J., Leontowicz, H., Leontowicz, M., et al. (2009). A comparative study of phenolic compounds and antioxidant and antiproliferative activities in frequently consumed raw vegetables. European Food Research and Technology, 228, 903-911.

Gu, L. W., House, S. E., Wu, X. L., Ou, B. X., \& Prior, R. L. (2006). Procyanidin and catechin contents and antioxidant capacity of cocoa and chocolate products. Journal of Agricultural and Food Chemistry, 54, 4057-4061.

Halliwell, B. (1996). Antioxidants in human health and disease. Annual Review of Nutrition, 16, 33-50.

Halvorsen, B. L., Holte, K., Myhrstad, M. C. W., Barikmo, I., Hvattum, E., Remberg, S F., et al. (2002). A systematic screening of total antioxidants in dietary plants. Journal of Nutrition, 132, 461-471. 
Hancock, R. D., Galpin, J. R., \& Viola, R. (2000). Biosynthesis of L-ascorbic acid (vitamin C) by Saccharomyces cerevisiae. Fems Microbiology Letters, 186 245-250.

Hart, D. J., \& Scott, K. J. (1995). Development and evaluation of an Hplc method for the analysis of carotenoids in foods, and the measurement of the carotenoid content of vegetables and fruits commonly consumed in the UK. Food Chemistry. 54, 101-111.

Havey, M. J., Galmarini, C. R., Gokce, A. F., \& Henson, C. (2004). QTL affecting soluble carbohydrate concentrations in stored onion bulbs and their association with flavor and health-enhancing attributes. Genome, 47, 463-468.

Helena, B., Pardo, R., Vega, M., Barrado, E., Fernandez, J. M., \& Fernandez, L. (2000). Temporal evolution of groundwater composition in an alluvial aquifer (Pisuerg River, Spain) by principal component analysis. Water Research, 34, 807-816.

Hogan, S., Zhang, L., Li, J. R., Zoecklein, B., \& Zhou, K. Q. (2009). Antioxidant properties and bioactive components of Norton (Vitis aestivalis) and Cabernet Franc (Vitis vinifera) wine grapes. LWT - Food Science and Technology, 42, 1269-1274.

Huang, D. J., Ou, B. X., \& Prior, R. L. (2005). The chemistry behind antioxidant capacity assays. Journal of Agricultural and Food Chemistry, 53, 1841-1856.

Huxley, R. R., \& Neil, H. A. W. (2003). The relation between dietary flavonol intake and coronary heart disease mortality: A meta-analysis of prospective cohort studies. European Journal of Clinical Nutrition, 57, 904-908.

Ikawa, M., Schaper, T. D., Dollard, C. A., \& Sasner, J. J. (2003). Utilization of FolinCiocalteu phenol reagent for the detection of certain nitrogen compounds. Journal of Agricultural and Food Chemistry, 51, 1811-1815.

Jordan, B. R., James, P. E., \& Mackerness, S. A. H. (1998). Factors affecting UV-Binduced changes in Arabidopsis thaliana L. gene expression: The role of development, protective pigments and the chloroplast signal. Plant and Cell Physiology, 39, 769-778.

Kahkonen, M. P., Hopia, A. I., Vuorela, H. J., Rauha, J. P., Pihlaja, K., Kujala, T. S., et al. (1999). Antioxidant activity of plant extracts containing phenolic compounds. Journal of Agricultural and Food Chemistry, 47, 3954-3962.

Kaspar, S. Matros, A. \& Mock, H. P. (2010). Proteome and flavonoid analysis reveals distinct responses of epidermal tissue and whole leaves upon UV-B radiation of barley (Hordeum vulgare L.) seedlings. Journal of Proteome Research, 9, 2402-2411.

Knekt, P., Kumpulainen, J., Jarvinen, R., Rissanen, H., Heliovaara, M., Reunanen, A et al. (2002). Flavonoid intake and risk of chronic diseases. American Journal of Clinical Nutrition, 76, 560-568.

Kurechi, T., Kikugawa, K., \& Kato, T. (1980). Studies on the antioxidants.13. Hydrogen donating capability of antioxidants to 2,2-diphenyl-1-picrylhydrazyl. Chemical and Pharmaceutical Bulletin, 28, 2089-2093.

Lake, J. A., Field, K. J., Davey, M. P., Beerling, D. J., \& Lomax, B. H. (2009). Metabolomic and physiological responses reveal multi-phasic acclimation of Arabidopsis thaliana to chronic UV radiation. Plant Cell and Environment, 32, 1377-1389.

Lanzotti, V. (2006). The analysis of onion and garlic. Journal of Chromatography A, $1112,3-22$

Lawson, L. D. Phytomedicines of Europe chemistry and biological activity. In Lawson, L. D., Bauer, R. 1998. Garlic: A review of its medicinal effects and indicated active compounds (pp. 176-209). Washington, DC: American Chemical Society.

Lester, G. E. (2006). Environmental regulation of human health nutrients (ascorbic acid, beta-carotene, and folic acid) in fruits and vegetables. Hortscience, 41 59-64.

Lu, J. M., Lin, P. H., Yao, Q. Z., \& Chen, C. Y. (2010). Chemical and molecula mechanisms of antioxidants: Experimental approaches and model systems. Journal of Cellular and Molecular Medicine, 14, 840-860.

Lundegardh, B., Botek, P., Schulzov, V., Hajslov, J., Stromberg, A., \& Andersson, H. C. (2008). Impact of different green manures on the content of S-alk(en)yl-Lcystelne Sulfoxides and l-ascorbic acid in leek (Allium porrum). Journal of Agricultural and Food Chemistry, 56, 2102-2111.

Mazid, M., Khan, T. A., \& Mohammad, F. (2011). Role of secondary metabolites in defense mechanisms of plants. Biology and Medicine, 3(2), 232-249.

Michalak, A. (2006). Phenolic compounds and their antioxidant activity in plants growing under heavy metal stress. Polish Journal of Environmental Studies, 15, 523-530

Mostafa, M. G., Mima, T., Ohnishi, S. T., \& Mori, K. (2000). S-allylcysteine ameliorates doxorubicin toxicity in the heart and liver in mice. Planta Medica, 66, 148-151.

Mota, C. L., Luciano, C., Dias, A., Barroca, M. J., \& Guine, R. P. F. (2010). Convective drying of onion: Kinetics and nutritional evaluation. Food and Bioproducts Processing, 88, 115-123.

Nencini, C., Menchiari, A., Franchi, G. G., \& Micheli, L. (2011). In vitro antioxidan activity of aged extracts of some Italian Allium species. Plant Foods for Human Nutrition, 66, 11-16.

Ou, B. X., Huang, D. J., Hampsch-Woodill, M., Flanagan, J. A., \& Deemer, E. K. (2002) Analysis of antioxidant activities of common vegetables employing oxygen radical absorbance capacity (ORAC) and ferric reducing antioxidant powe (FRAP) assays: A comparative study. Journal of Agricultural and Food Chemistry. $50,3122-3128$

Perez-Jimenez, J., Arranz, S., Tabernero, M., Diaz-Rubio, M. E., Serrano, J., Goni, I. et al. (2008). Updated methodology to determine antioxidant capacity in plant foods, oils and beverages: Extraction, measurement and expression of. Food Research International, 41, 274-285.

Peterson, G. L. (1979). Review of the foline phenol protein quantitation method of Lowry, Rosebrough, Farr and Randall. Analytical Biochemistry, 100, 201-220.
Platteau, J., Van Gijseghem, D., \& Van Bogaert, T. (Eds.). (2010). Landbouwrapport 2010. Brussel: Departement Landbouw en Visserij.

Prior, R. L., \& Cao, G. H. (1999). In vivo total antioxidant capacity: Comparison of different analytical methods. Free Radical Biology and Medicine, 27, 1173-1181.

Prior, R. L., Hoang, H., Gu, L. W., Wu, X. L., Bacchiocca, M., Howard, L., et al. (2003). Assays for hydrophilic and lipophilic antioxidant capacity (oxygen radical absorbance capacity (ORAC(FL))) of plasma and other biological and food samples. Journal of Agricultural and Food Chemistry, 51, 3273-3279.

Prior, R. L., Wu, X. L., \& Schaich, K. (2005). Standardized methods for the determination of antioxidant capacity and phenolics in foods and dietary supplements. Journal of Agricultural and Food Chemistry, 53, 4290-4302.

Proteggente, A. R., Pannala, A. S., Paganga, G., Van Buren, L., Wagner, E., Wiseman, S. et al. (2002). The antioxidant activity of regularly consumed fruit and vegetables reflects their phenolic and vitamin $\mathrm{C}$ composition. Free Radical Research, 36, 217-233.

Rodrigues, A. S., Perez-Gregorio, M. R., Garcia-Falcon, M. S., Simal-Gandara, J., \& Almeida, D. P. F. (2011). Effect of meteorological conditions on antioxidant flavonoids in Portuguese cultivars of white and red onions. Food Chemistry, 124, 303-308.

Serrano, J., Goni, I., \& Saura-Calixto, F. (2007). Food antioxidant capacity determined by chemical methods may underestimate the physiological antioxidant capacity. Food Research International, 40, 15-21.

Shen, G. X. (2010). Oxidative stress and diabetic cardiovascular disorders: Roles of mitochondria and NADPH oxidase. Canadian Journal of Physiology and Pharmacology, 88, 241-248.

Singh, S. V., Pan, S. S., Srivastava, S. K., Xia, H., Hu, X., Zaren, H. A., et al. (1998). Differential induction of $\mathrm{NAD}(\mathrm{P}) \mathrm{H}$ : Quinone oxidoreductase by anticarcinogenic organosulfides from garlic. Biochemical and Biophysical Research Communications, 244, 917-920.

Singleton, V. L., \& Rossi, J. A. (1965). Colorimetry of total phenolics with phosphomolybdic-phosphotungstic acid reagents. American Journal of Enology and Viticulture, 16, 144-158.

Tafulo, P. A. R., Queiros, R. B., Delerue-Matos, C. M., \& Sales, M. G. F. (2010). Control and comparison of the antioxidant capacity of beers. Food Research International, $43,1702-1709$.

Teow, C. C., Truong, V. D., McFeeters, R. F., Thompson, R. L., Pecota, K. V., \& Yencho, G. C. (2007). Antioxidant activities, phenolic and beta-carotene contents of sweet potato genotypes with varying flesh colours. Food Chemistry, 103, 829-838.

Thaipong, K., Boonprakob, U., Crosby, K., Cisneros-Zevallos, L., \& Byrne, D. H. (2006) Comparison of ABTS, DPPH, FRAP, and ORAC assays for estimating antioxidant activity from guava fruit extracts. Journal of Food Composition and Analysis, 19, 669-675.

Tsoukalas, D. S., Katsanidis, E., Marantidou, S., \& Bloukas, J. G. (2011). Effect of freeze-dried leek powder (FDLP) and nitrite level on processing and quality characteristics of fermented sausages. Meat Science, 87, 140-145.

U.S. Department of Agriculture (2010). Oxygen Radical Absorbance Capacity (ORAC) of Selected Foods, Release 2. Nutrient Data laboratory Home.

van Duijnhoven, F. J. B., Bueno-de-Mesquita, H. B., Ferrari, P., Jenab, M., Boshuizen, H. C., Ros, M. M., et al. (2009). Fruit, vegetables, and colorectal cancer risk: The European Prospective Investigation into Cancer and Nutrition. American Journal of Clinical Nutrition, 89, 1441-1452.

Vandekinderen, I., Van Camp, J., Devlieghere, F., Ragaert, P., Veramme, K., Bernaert, $\mathrm{N}$., et al. (2009). Evaluation of the use of decontamination agents during freshcut leek processing and quantification of their effect on its total quality by means of a multidisciplinary approach. Innovative Food Science and Emerging Technologies, 10, 363-373.

Vinson, J. A., Hao, Y., Su, X. H., \& Zubik, L. (1998). Phenol antioxidant quantity and quality in foods: Vegetables. Journal of Agricultural and Food Chemistry, 46, 3630-3634

Vinson, J. A., Proch, J., \& Bose, P. (2001). Determination of quantity and quality of polyphenol antioxidants in foods and beverages. Flavonoids and Other Polyphenols, 335, 103-114.

Wang, Y. X., \& Frei, M. (2011). Stressed food - The impact of abiotic environmental stresses on crop quality. Agriculture Ecosystems and Environment, 141, 271-286.

Waterman, P. G., \& Mole, S. (1994). Analysis of phenolic plant metabolites. Oxford: Blackwell Scientific Publications.

Wilkens, R. T., Spoerke, J. M., \& Stamp, N. E. (1996). Differential responses of growth and two soluble phenolics of tomato to resource availability. Ecology, 77, 247-258.

Xiao, D. H., Pinto, J. T., Gundersen, G. G., \& Weinstein, I. B. (2005). Effects of a series of organosulfur compounds on mitotic arrest and induction of apoptosis in colon cancer cells. Molecular Cancer Therapeutics, 4, 1388-1398.

Yin, M. C., Hwang, S. W., \& Chan, K. C. (2002). Nonenzymatic antioxidant activity of four organosulfur compounds derived from garlic. Journal of Agricultural and Food Chemistry, 50, 6143-6147.

Zhou, K. Q., \& Yu, L. L. (2006). Total phenolic contents and antioxidant properties of commonly consumed vegetables grown in Colorado. LWT - Food Science and Technology, 39, 1155-1162.

Zulueta, A., Esteve, M. J., \& Frigola, A. (2009). ORAC and TEAC assays comparison to measure the antioxidant capacity of food products. Food Chemistry, 114, 310-316. 